\title{
Butterflyfishes feed on externally brooded larvae of the blue coral, Heliopora coerulea
}

Received: 30 August 2009/Accepted: 29 September 2009/Published online: 22 October 2009

(C) Springer-Verlag 2009

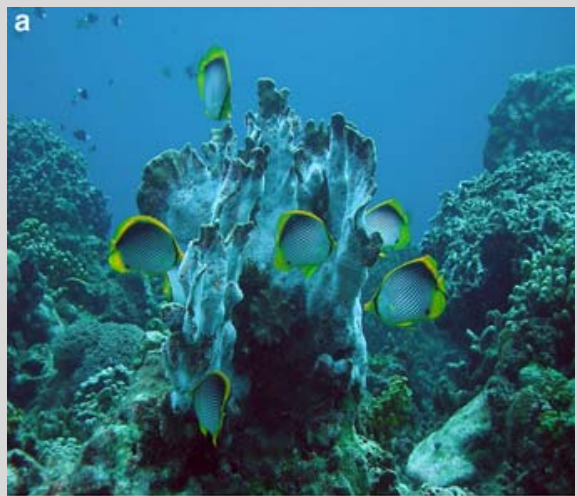

Aside from consumption of coral soft tissues, predation of propagules presents a significant trophic link between corals and reef fishes (Pratchett et al. 2001). Corallivorous butterflyfishes mainly prey on corals by biting soft tissues by means of their specialized feeding apparatus (Motta 1988), though two Chaetodon spp. were observed to feed on the eggs of soft corals in the plankton during mass spawning (Alino and Coll 1989).

During the annual brooding of the blue coral, Heliopora coerulea in April 2009 at a reef in the Malilnep channel near Bolinao, northwestern Philippines (16 26 $\left.23.5^{\prime \prime} \mathrm{N} ; 119^{\circ} 56^{\prime} 43.1^{\prime \prime} \mathrm{E}\right)$, several butterflyfishes (Chaetodon melannotus, C. auriga, and C. vagabundus) were observed to aggregate around three gravid colonies (5-10 $\mathrm{m}$ apart) among seven such colonies on a 50-m transect. The butterflyfishes were biting on parts of the colonies with larvae being brooded at the surface (Fig. 1). We infer that these fishes were feeding on the brooded larvae rather than coral tissues as they did not bite on the apical parts of the colonies without larvae and did not aggregate around 33 non-gravid $H$. coerulea colonies on the transect.

Aggregations of up to ten individuals persisted for at least $30 \mathrm{~min}$. This observation presents a new perspective on how corallivorous butterflyfishes may interact with their coral prey and is the first report of Chaetodon spp. feeding on brooded coral larvae (G.R. Allen, pers.

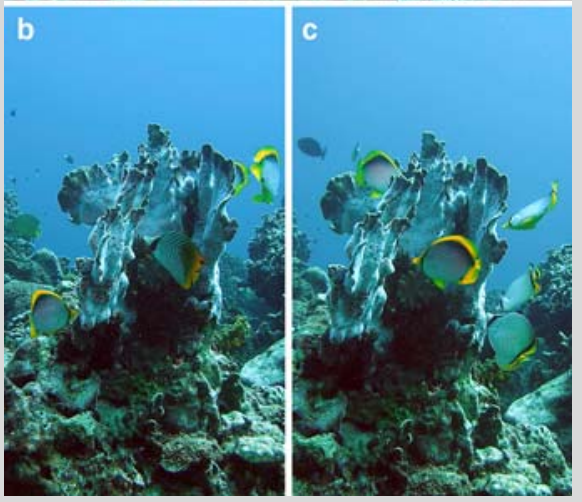

comm.). For the butterflyfishes, the consumption of high lipid content ( $41 \%$ dry wt., Harii et al. 2007) blue coral larvae may provide a fitness advantage, similar to the enhanced larval quality in damselfish that have consumed coral spawn (McCormick 2003). For the corals, this observation highlights a potentially significant source of larval mortality and a disadvantage of external benthic brooding.

Individuals of three other butterflyfish species (C. kleinii, C. lunula, and C. rafflesi) also visited the gravid colonies with aggregations of feeding congeners, but were not observed to feed.

Acknowledgments We are grateful to G.R. Allen (Western Australian Museum) for confirming the novelty of the phenomenon and to M. R. C. Rodrigueza-Villanueva and P. Cabaitan for help with figure preparation. We thank the GEF/World Bank Coral Reef Targeted Research program for support.

References

Fig. 1 Colony of Heliopora coerulea with externally brooded larvae being preyed upon by Chaetodon melannotus (a), together with C. auriga (b) and C. vagabundus (c). Larvae appear as white patches on colony surface

Alino PM, Coll JC (1989) Observations of the synchronized mass spawning and postsettlement activity of octocorals on the Great Barrier Reef, Australia: biological aspects. Bull Mar Sci 45:697-707

Harii S, Nadaoka K, Yamamoto M, Iwao K (2007) Temporal changes in settlement, lipid content and lipid composition of larvae of the spawning hermatypic coral Acropora tenuis. Mar Ecol Prog Ser 346:89-96

McCormick MI (2003) Consumption of coral propagules after mass spawning enhances larval quality of damselfish through maternal effects. Oecologia 136:37-45

Motta PJ (1988) Functional morphology of the feeding apparatus of ten species of Pacific butterflyfishes (Perciformes, Chaetodontidae): an ecomorphological approach. Environ Biol Fish 22:39-67

Pratchett MS, Gust N, Goby G, Klanten SO (2001) Consumption of coral propagules represents a significant trophic link between corals and reef fish. Coral Reefs 20:13-17

R. D. Villanueva $(\bowtie)$

The Marine Science Institute, University of the Philippines, Diliman, 1101 Quezon City, Philippines

e-mail: villanuevr@yahoo.com

A. J. Edwards

School of Biology, Newcastle University, Newcastle upon Tyne NE1 7RU, UK

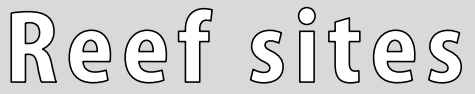

Coral Reefs (2010) 29:105

DOI $10.1007 / \mathrm{s} 00338-009-0553-1$ 